\title{
Recurrent outbreaks of disease in sea urchins Strongylocentrotus droebachiensis in Nova Scotia: evidence for a link with large-scale meteorologic and oceanographic events
}

\author{
Robert E. Scheibling*, Allan W. Hennigar \\ Department of Biology, Dalhousie University, Halifax, Nova Scotia, Canada B3H 4J1
}

\begin{abstract}
Recurrent outbreaks of a disease (paramoebiasis, caused by a marine amoeba Paramoeba invadens) result in mass mortalities of sea urchins Strongylocentrotus droebachiensis in the rocky subtidal zone of the Atlantic coast of Nova Scotia (Canada). Recent epizootics in 1993 and 1995, like those which occurred in the early 1980s, were associated with unusually warm sea surface temperatures (SST) in late summer/fall of each year. Disease outbreaks were localized in 1993 and did not completely eliminate sea urchin populations, whereas a widespread epizootic caused near-complete mortality over $-130 \mathrm{~km}$ of coast (straight-line distance) in 1995. Interanrual differences in the extent of mortality were related to differences in the temperature regime (peak temperatures prevalled longer in 1995), which is consistent with previously described patterns. The absence of mortality in 1994 is attributed to the inability of $P$. invadens to survive low $\left(<0^{\circ} \mathrm{C}\right)$ winter temperatures, suggesting it is an exotic pathogen. Recent outbreaks of paramoebiasis were associated with increased proximity to the coast of warm water masses in the summer/fall, as indicated by satellite-derived and ground-truthed charts of SST Intrusions of Gulf Stream water as warm-core rings, which entrain and mix with shelf water, may contribute to coastal warming, although the frequency of ring formation was fairly constant among years (from SST charts, 1991 to 1995). Disease outbreaks during the past 2 decades have also been associated with years of relatively high tropical storm and hurricane activity in the northwest Atlantic (from records of the National Hurricane Center USA, 1976 to 1995), which may influence advection and mixing off Nova Scotia. These observations suggest that large-scale oceanographic and meteorologic processes may play a role in triggering epizootics by transporting the infective agent (if $P$. invadens is an exotic species) and/or creating environmental conditions conducive to the propagation of the disease. Because of the stochastic nature of these external events, the dynamics of the rocky subtidal ecosystem appear to be highly unpredictable. Severe disease outbreaks which eliminate sea urchins cause major changes in community structure as barren grounds, previously dominated by sea urchins, are colonized by kelps and other macroalgae. This has important implications for coastal fisheries, particularly the rapidly expanding sea urchin fishery.
\end{abstract}

KEY WORDS: Disease - Mass mortality · Pathogen Physical oceanography $\cdot$ Rocky subtıdal community - Sea urchin - Strongylocentrotus droebachiensis . Temperature

\section{INTRODUCTION}

During the past 2 decades, mass mortalities of sea urchins, attributed to disease, have been reported globally [e.g. Strongylocentrotus fransciscanus in California, USA (Johnson 1971, Pearse et al. 1977);

\footnotetext{
•E-mail: rescheib@is.dal.ca
}

Diadema antillarum in the Caribbean (Lessios et al. 1984, Lessios 1988); Paracentrotus lividus in the Mediterranean (Boudouresque et al. 1980, Maes \& Jangoux 1984) and Brittany, France (Maes \& Jangoux 1985); Strongylocentrotus droebachiensis in Nova Scotia, Canada (Scheibling 1984, 1986, Miller 1985) and Norway (Hagen 1987, 1992, Skadsheim et al. 1995, Sivertsen 1996)]. Although the ecological impacts of 
epizootics on sea urchin populations and benthic communities have been well documented, the pathogenesis and etiology of these diseases are still poorly understood. With the exception of the macroparasitic infection of $S$. droebachiensis in Norway (Jones \& Hagen 1987. Hagen 1996; but see also Christie et al. 1995, Stien et al. 1995), microbial pathogens are suspected, but only in the case of $S$. droebachiensis in Nova Scotia has a specific microparasitic agent been identified (Jones 1985, Jones \& Scheibling 1985)

Between 1980 and 1983, mass mortalities of Strongylocentrotus droebachiensis occurred along the Atlantic coast of Nova Scotia (Miller \& Colodey 1983, Miller 1985, Scheibling 1986). A new species of marine amoeba, Paramoeba invadens, known only from the tissues of diseased $S$. droebachiensis, was identified as the pathogenic agent (Jones 1985, Jones \& Scheibling 1985). P. invadens has not been found in healthy sea urchins (from areas or years in which epizootics did not occur) or in the natural environment (Jones et al. 1985a, b, Jellett et al. 1989). The amoeba is waterborne and healthy sea urchins can be experimentally infected by exposure to water flowing over diseased conspecifics (Scheibling \& Stephenson 1984, Jones \& Scheibling 1985).

Temperature is a key factor regulating the transmission and progression of paramoebiasis in Strongylocentrotus droebachiensis (reviewed by Scheibling 1988). Outbreaks of disease in the early 1980 s occurred in late summer and fall (the peak in the annual temperature cycle) in unusually warm years (Miller \& Colodey 1983, Scheibling \& Stephenson 1984, Miller 1985, Scheibling 1986). As temperatures declined towards winter, the disease was arrested and infected sea urchins recovered. Interannual variation in the severity of these epizootics was directly related to the duration of high sea temperatures (Scheibling \& Stephenson 1984, Miller 1985, Scheibling 1986). In laboratory experiments, Scheibling \& Stephenson (1984) showed that the rate of progression of the disease in $S$. droebachiensis increased exponentially between 12 and $20^{\circ} \mathrm{C}$ (the upper thermal tolerance limit of the sea urchin); below $12^{\circ} \mathrm{C}$ transmission and/or progression did not occur. Jellett \& Scheibling (1988a) showed that this pattern of disease progression was related to the temperature dependence of growth rate of Paramoeba invadens in culture.

The etiology of paramoebiasis remains elusive but 2 alternative hypotheses have been proposed to explain recurrent outbreaks of the disease (Scheibling 1988). The 'endemic hypothesis' is that Paramoeba invadens naturally co-occurs with Strongylocentrotus droebachiensis and becomes parasitic and/or pathogenic during periods of high temperatures. The 'exotic hypothesis' is that $P$. invadens is an exotic species peri- odically introduced to the coastal waters of Nova Scotia by ocean currents. The exotic hypothesis implies that outbreaks of disease are contingent on large-scale oceanographic processes which cause transport and mixing of shelf water along the coast. As yet, there is little published evidence to support either of these hypotheses, although the inability of $P$, invadens to survive in culture at $2^{\circ} \mathrm{C}$ (Jellett \& Scheibling 1988a), which is above the winter minimum along the Atlantic coast of Nova Scotia $\left(0\right.$ to $\left.-2^{\circ} \mathrm{C}\right)$, favours the exotic hypothesis.

In this study, we report on recurrent outbreaks of paramoebiasis in Strongylocentrotus droebachiensis on the Atlantic coast of Nova Scotia in 1993 and 1995, the first of these events documented since the early 1980 s. We examine the relationship of these recent epizootics to seasonal and interannual variation in sea temperatures along the coast, and to long-term temperature records for Malifax Harbour, to establish consistency with previously reported patterns. We also examine satellite-derived records of oceanographic (sea surface temperatures, Gulf Stream warm-core rings) and meteorologic (tropical storms, hurricanes) processes which may effect large-scale mixing and advective transport of an exotic pathogen.

\section{METHODS}

Monitoring sea urchin mass mortality. After the mass mortalities in the early 1980s, populations of Strongylocentrotus droebachiensis became re-established in the rocky coastal zone of Nova Scotia in the early 1990 s (Scheibling 1994, 1996) to the extent that they began to support an expanding roe fishery (Scheibling \& Hatcher 1993). As part of a broader study of sea urchin-kelp dynamics along this coast (Scheibling et al. 1994, unpubl. data), we monitored sea urchin populations at 2 sites (separated by $26 \mathrm{~km}$ ) along the southwestern coast of Nova Scotia between June 1992 and November 1995: Little Duck Island $\left(44^{\circ} 22^{\prime} \mathrm{N}\right.$, $\left.64^{\circ} 11^{\prime} \mathrm{W}\right)$, off an exposed headland at the mouth of Mahone Bay, and Mill Cove $\left(44^{\circ} 35^{\prime} \mathrm{N}, 64^{\circ} 03^{\prime} \mathrm{W}\right.$ ) in St. Margaret's Bay, a large semi-protected embayment. Depth ranged from 6 to $9 \mathrm{~m}$ at both sites and the substratum varied from bedrock outcrops to boulders. Bottom sea water temperature (at $8 \mathrm{~m}$ depth) was continuously recorded at each site between April 1994 and November 1995 using HoboTemp ${ }^{\text {rM }}$ (Onset Computer Corporation, Pocasset, MA, USA) thermographs.

At both sites, dense aggregations (or fronts) of sea urchins had formed along the offshore border of kelp beds and were destructively grazing the kelp, creating barren grounds in their wake (Scheibling et al. 1994). Sea urchin density was measured at 1 to 2 mo intervals 
in a series of contiguous $0.25 \mathrm{~m}^{2}$ quadrats $(\mathrm{n}=20)$ along each of 4 transects of $0.5 \times 10 \mathrm{~m}\left(5 \mathrm{~m}^{2}\right)$. The transects extended perpendicular to the kelp bed border from the leading edge of the sea urchin front into the barren grounds and were spaced at $10 \mathrm{~m}$ intervals. Crevices, undersides of cobbles and boulders, algal turfs, and holdfasts of kelp were carefully searched for small and cryptic sea urchins. Mean sea urchin density at each sampling date was estimated by pooling quadrat counts across the 4 transects $(n=80)$. Symptoms of paramoebiasis were recorded as described by Jones et al. (1985a). After mass mortality of Strongylocentrotus droebachiensis in September 1995, surviving sea urchins were censused at Little Duck Island on 24 October 1995 by counting all live sea urchins in a transect of $3 \times 50 \mathrm{~m}\left(150 \mathrm{~m}^{2}\right)$ along the former sea urchin front and in 2 transects of $2 \times 50 \mathrm{~m}\left(100 \mathrm{~m}^{2}\right)$ in the barren grounds (roughly parallel to the front transect and 10 and $20 \mathrm{~m}$ respectively from the kelp bed). A sample of 6 sea urchins collected at this time were examined for the presence of Paramoeba invadens by culturing radial nerve and/or gonadal tissue as described by Jellett \& Scheibling (1988a, b).

The extent of the sea urchin mass mortalities elsewhere along the Atlantic coast of Nova Scotia in 1995 was determined from reports of sea urchin harvesters, obtained either through personal interviews or written questionnaires. The harvesters were asked when and where they first observed unusual mortality of sea urchins on their fishing grounds. Because the economic threat of disease caused considerable concern among sea urchin harvesters in Nova Scotia, they conducted intensive surveys of their fishing grounds using scuba in September and October 1995 (while the fishery was temporarily shut down by the Department of Fisheries and Oceans, Canada). Therefore, we believe these reports are a reliable record of the spread and extent of the disease at this time.

Sea surface temperatures and warm-core ring activity. To examine interannual variation in sea surface temperature (SST) during the seasonal peak (when outbreaks of paramoebiasis occur), deviations from long-term averages (1926 to 1967, Lauzier \& Hull 1969) in mean monthly temperatures between August and October 1955 to 1995 were calculated from temperature records for Halifax Harbour (Gregory et al. 1993, 1994, Department of Fisheries and Oceans, Canada, unpubl. data).

To examine coastal warming and large-scale patterns of advection and mixing during August and September 1991 to 1995 , SST charts $\left(2^{\circ} \mathrm{C}\right.$ isotherms) in the northwest Atlantic were obtained from the Canadian Forces Meteorology and Oceanography Branch, Maritime Atlantic Headquarters (METOC) Halifax, Nova Scotia. These maps are generated at 3 to $4 \mathrm{~d}$ intervals from

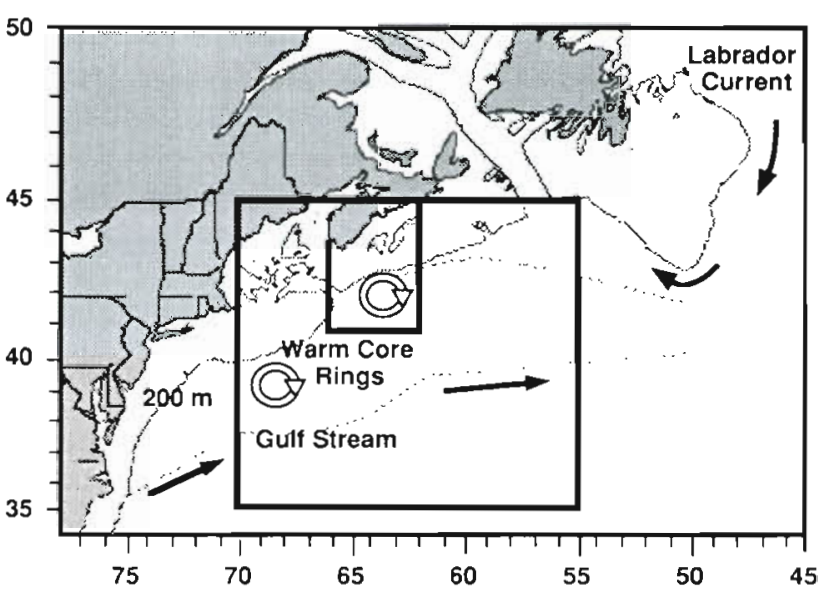

Fig. 1. Northwest Atlantic showing continental shelf $(200 \mathrm{~m}$ isobath), major oceanographic features, and study grids for measures of coastal warming (inner grid) and storm activity (outer grid)

satellite-derived thermal imagery augmented by temperature observations from ships of opportunity. A study grid $\left(41^{\circ}-44^{\circ} \mathrm{N}, 62^{\circ}-66^{\circ} \mathrm{W}\right)$ was delineated to encompass the continental shelf and adjacent slope water south of the mainland coast of Nova Scotia (excluding the northern tip and Cape Breton Island) to ca 200 to $300 \mathrm{~km}$ offshore (Fig. 1). An index of coastal warming was developed on a 6 point scale based on the proximity to the coast of the 16,18 and $20^{\circ} \mathrm{C}$ isotherms (Table 1). A mean index was calculated for the first and second half of each month by averaging the indices for 3 to 5 SST maps within each $\sim 2$ wk period.

The METOC SST charts also were used to monitor intrusions of Gulf Stream water along the Scotian Shelf as warm-core rings. These features were discernible as rings or spiralling filaments of seawater $>24^{\circ} \mathrm{C}$. To obtain an index of warm-core ring activity within our SST study grid, the number of warm-core rings within

Table 1 Coastal warming index for Scotian Shelf $\left(41^{\circ}-44^{\circ} \mathrm{N}\right.$, $62^{\circ}-66^{\circ} \mathrm{W}$ ) based on satellite-derived and ground-truthed charts of SST (from Canadian Forces METOC Centre)

\begin{tabular}{|ll|}
\hline Index & \multicolumn{1}{c|}{ Position of isotherms } \\
\hline 1 & $16^{\circ} \mathrm{C}$ isotherm does not intercept coast \\
2 & $16^{\circ} \mathrm{C}$ isotherm intercepts $>20 \%$ of coast, \\
& $18^{\circ} \mathrm{C}$ isotherm $>1^{\circ}$ latitude from coast \\
3 & $16^{\circ} \mathrm{C}$ isotherm intercepts $>60 \%$ of coast, \\
& $18^{\circ} \mathrm{C}$ isotherm $<1^{\circ}$ latitude from coast \\
& $16^{\circ} \mathrm{C}$ isotherm intercepts $>80 \%$ of coast \\
4 & $18^{\circ} \mathrm{C}$ isotherm intercepts 20 to $60 \%$ of coast \\
& $18^{\circ} \mathrm{C}$ isotherm intercepts $>60 \%$ of coast, \\
5 & $20^{\circ} \mathrm{C}$ isotherm $>1^{\circ}$ latitude from coast \\
& $18^{\circ} \mathrm{C}$ isotherm intercepts $>80 \%$ of coast, \\
6 & $20^{\circ} \mathrm{C}$ isotherm $<1^{\circ}$ latitude from coast \\
&
\end{tabular}


or contacting the grid for each mapping interval was recorded. A mean index was calculated for the first and second half of August and September by averaging the indices for 3 to 5 SST maps within each -2 wk period.

Storm activity in the northwestern Atlantic. To examine severe storm activity in the northwestern Atlantic adjacent to the Scotian Shelf, satellite-derived charts of tropical storm and hurricane tracks were obtained from the National Hurricane Center, NOAA, through the Internet (http://www.nhc noaa.gov/tracks. html). These maps show storm tracks for all tropical storms and hurricanes in the Atlantic for each year. Associated data reports provide 6-hourly (00:00, 06:00, 12:00, 18:00 h UTC) storm center locations (latitude, longitude) and intensities (maximum surface wind speeds in knots, minimum central pressures in millibars). A study grid ( $35^{\circ}$ to $45^{\circ} \mathrm{N}, 55^{\circ}$ to $70^{\circ} \mathrm{W}$ ) was delineated to encompass the northeastern seaboard of the contincntal USA, south of Nova Scotia (Fig. 1). A storm index was calculated by recording the intensity and duration of each tropical storm or hurricane entering this grid for each year between 1976 and 1995. The average maximum wind speed for each full or partial day that a particular storm was in the grid was multiplied by the proportion of that day in the grid, and the index was the sum of the product (knot days) for all storm days within the grid in August and September.

\section{RESULTS}

\section{Patterns of mass mortality of sea urchins}

Between June 1992 and September 1993, dense fronts of Strongylocentrotus droebachiensis at Little Duck Island and Mill Cove advanced shoreward at rates of 1 to $4 \mathrm{~m} \mathrm{mo}^{-1}$, destructively grazing the kelp beds at each site (Scheibling et al. 1994, unpubl. data). Sea urchin density in the recently formed barren grounds bordering the kelp bed was $\sim 3$ times higher at Little Duck Island (grand mean for 5 samples between June and September 1993: 30.2 sea urchins per $0.25 \mathrm{~m}^{2}$; Fig 2a) than at Mill Cove (11.2 sea urchins per $0.25 \mathrm{~m}^{2}$; Fig 2b), with aggregations of up to $\sim 100$ sea
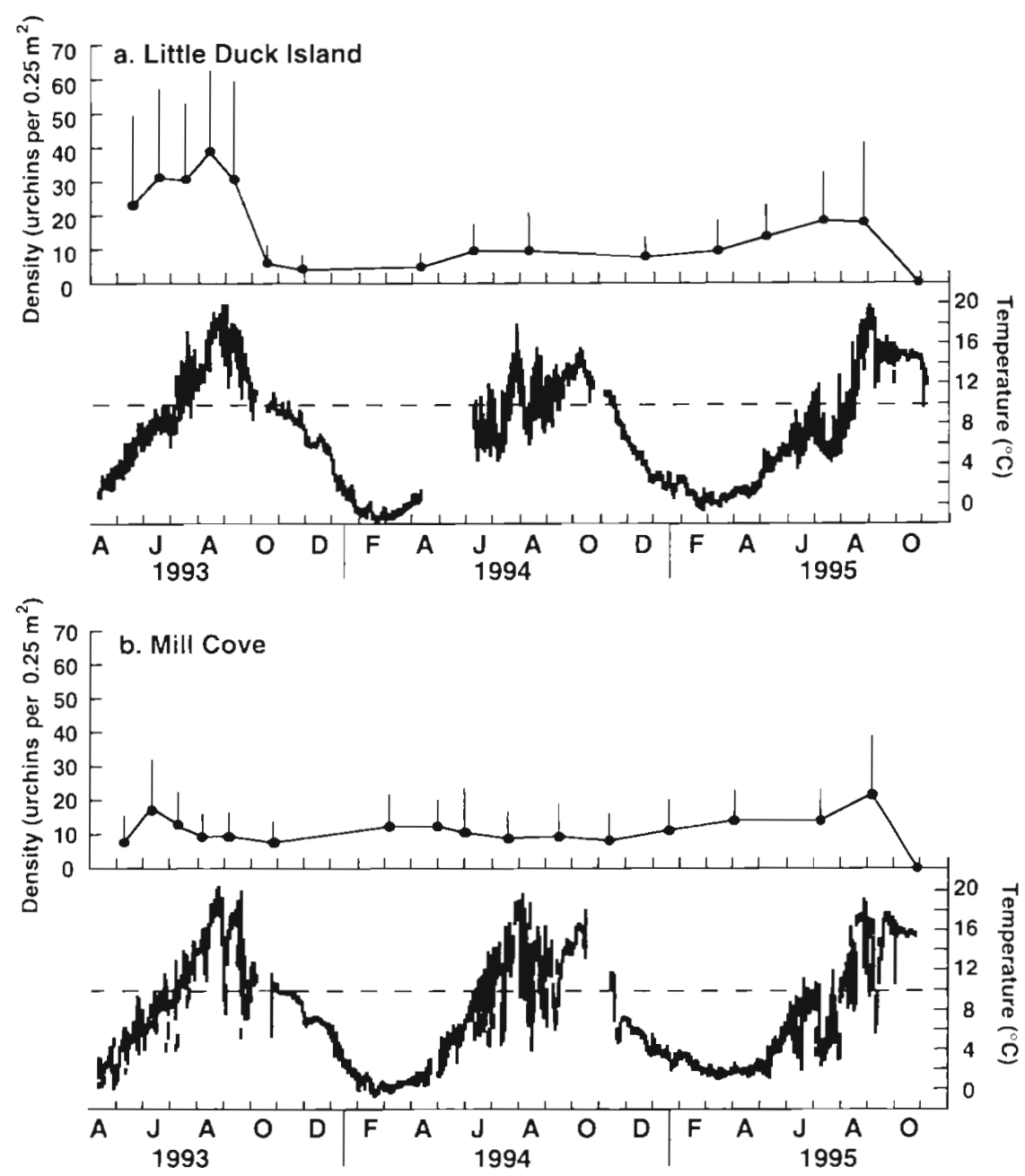

Fig. 2. Sea urchin density (mean + $\mathrm{SD}$ ) and daily range of bottom temperatures at (a) Little Duck Island and (b) Mill Cove between April 1994 and November 1995 
urchins per $0.25 \mathrm{~m}^{2}$ along the leading edge of the front at the former site. On 8 September 1993, most sea urchins in the front at Little Duck Island exhibited characteristic symptoms of paramoebiasis: loss of attachment to the substratum, drooping spines and tube feet, and gaping of the peristomial membrane (Jones et al. 1985a). By 17 September, sea stars (Asterias vulgaris, $A$. forbesi) and crabs (Cancer irroratus, $C$. borealis) were abundant along the front where they scavenged moribund sea urchins. By 14 October 1993. sea urchin density at Little Duck Island was reduced to 39 sea urchins per $0.25 \mathrm{~m}^{2}$ (Fig. 2a), and numerous tests of dead sea urchins had accumulated in depressions on the seabed. Therefore, the disease either directly or indirectly (by increasing susceptibility to predators) resulted in $87 \%$ mortality of the sea urchin population at Little Duck Island. Although a few sea urchins at Mill Cove exhibited symptoms of paramoebiasis in September 1993, there was no evidence of mass mortality. There was no significant decline in sea urchin density (Fig. 2a) between September and October 1993 (Student's $t$-test, $t=1.21, \mathrm{df}=158, \mathrm{p}>0.20$ ), nor did we observe an unusual accumulation of tests.

Surviving sea urchins at both sites appeared to recover from the disease over the winter. There were no signs of paramoebiasis or unusual mortality of Strongylocentrotus droebachiensis at either site between November 1993 and August 1995. The increase in sea urchin density at both sites in July/August 1995 reflects an increase in aggregation as grazing fronts (particularly at Little Duck Island) began to re-form along the border of the kelp bed. In September 1995, a recurrence of disease virtually eliminated sea urchins at both sites (Fig. 2a, b). On 24 October, a total of only 9 live sea urchins were counted in 2 transects of $100 \mathrm{~m}^{2}$ in the barren grounds at Little Duck Island; another 70 live sea urchins were counted in a transect of $150 \mathrm{~m}^{2}$ along the front. Given that average density of sea urchins in the barren grounds at Little Duck Island was $\sim 19$ sea urchins per $0.25 \mathrm{~m}^{2}$ immediately prior to the die-off (Fig. 2a), the estimated mortality rate of sea urchins in 1995 was $>99 \%$. No surviving sea urchins were observed in diving surveys at Mill Cove on 12 October 1995.

Reports of sea urchin harvesters established the range of mass mortalities along the Atlantic coast of Nova Scotia in 1995 from Lockeport on the southwestern shore (south of Halifax) to Jeddore on the eastern shore (north of Halifax) (Fig. 3). Mass mortalities of Strongylocentrotus droebachiensis were first reported on 16 September in Mahone Bay (A. Schnare pers. comm.). The disease appeared to spread rapidly along the southwestern shore causing nearly complete mortality of sea urchins between Mahone Bay and Port Mouton Island by late October (C. Theriault pers. comm.). Sea urchins in Shelburne Harbour immediately to the south appeared unaffected (R. Garland pers. comm.). To the north of Mahone Bay, mass mortalities were reported around Halifax on 30 September (P. Boudreski pers. comm.). Along the eastern shore,
Fig. 3. Range of mass mortalities of sea urchins during outbreaks of disease in the shallow subtidal zone along the Atlantic coast of Nova Scotia, 1980 to 1983 (after Miller 1985, Scheibling 1986 ) and 1993 to 1995 (this study): black bars, nearcomplete mortality; stippled bars, partial mortality: white bars, areas where sea urchins were eliminated in the previous 1 or 2 yr. Observations of sea urchin populations at specific sites in 1995: near-complete mortality; (o) partial mortality; (o) no mortality

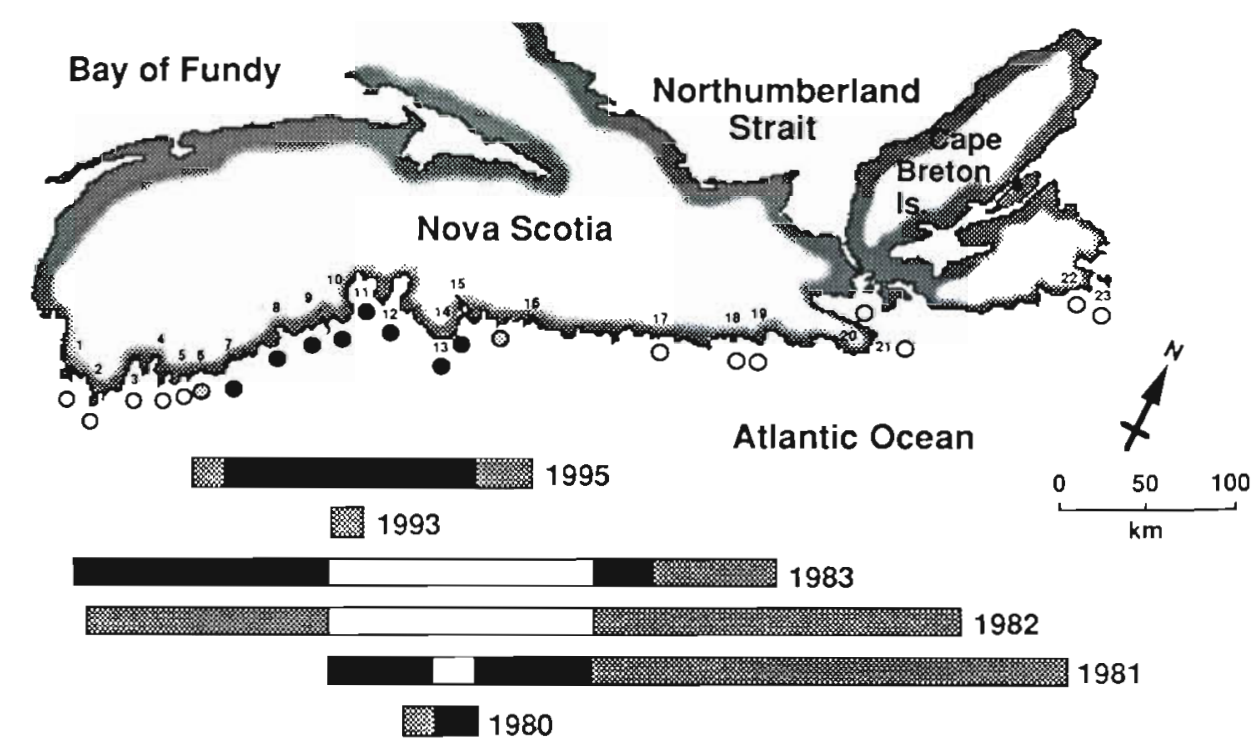

1 - Cape Sable Island

2 - Port La Tour

3 - Shelburne Harbour

4 - Lockeport

5 - Jones Harbour

6 - Port Joll Point
7 - Port Mouton Isiand

8 - Port Medway

9 - La Have Island

10. Little Duck Island

11 - Mahone Bay

12 - St. Margarets Bay
13 - Cranberry Cove

14 - Herring Cove

15 - Hallfax

16 - Jeddore

17 - Gold Island

18 - Wine Harbour
19 - Port Bickerton

20 - Fox Island

21 - Canso

22 - Louisbourg

23 - Main-a-Dieu Bay 
there were scattered reports of the disease between Halifax and Jeddore in October and November. Further east along the coast to Cape Breton Island, sea urchin populations were apparently unaffected (M. Craig pers. comm.). In total, the epizootic of 1995 caused near-complete mortality of $S$. droebachiensis along $\sim 130 \mathrm{~km}$ (straight-line distance) of the Atlantic coast, and at least partial and localized mortalities along another $\sim 40 \mathrm{~km}$.

The cause of the second epizootic was confirmed as paramoebiasis. Radial nerve and/or gonadal tissues of all 6 sea urchins from a sample collected at Little Duck Island on 24 October contained the pathogen Paramoeba invadens (Jones 1985).

\section{Spatial and temporal patterns in sea temperature}

The outbreak of paramoebiasis at Little Duck Island in September 1993 was coincident with the annual peak in sea temperature, which reached daily averages of $\sim 19^{\circ} \mathrm{C}$ at $8 \mathrm{~m}$ depth (Fig 2a). Peak temperatures at $8 \mathrm{~m}$ were similar at Mill Cove in 1993, although sharp dips to $\sim 8^{\circ} \mathrm{C}$ (probably reflecting wind-driven upwelling events) occurred in late August and late September (Fig. 2b). The mass mortality at Little Duck Island was arrested after the temperature dropped below $10^{\circ} \mathrm{C}$ in October. The winter minima were -1 and $-2^{\circ} \mathrm{C}$ in February 1994 at Little Duck Island and Mill Cove respectively.

Peak temperatures at Little Duck Island were much lower in 1994 than in 1993, rarely exceeding $14^{\circ} \mathrm{C}$ with dips below $10^{\circ} \mathrm{C}$ in August and below $12^{\circ} \mathrm{C}$ in September (Fig. 2a). Although peak temperatures approached $18^{\circ} \mathrm{C}$ at Mill Cove in late July 1994, daily averages were generally $<14^{\circ} \mathrm{C}$ in August and September, periodically falling as low as 4 to $6^{\circ} \mathrm{C}$ (Fig. 2b).
In 1995, following a protracted drop in July, temperature rose rapidly in August at both sites to peak daily averages of 18 to $19^{\circ} \mathrm{C}$ (Fig. 2a, b). At Little Duck Island, temperatures remained high $\left(15\right.$ to $\left.16^{\circ} \mathrm{C}\right)$ throughout September (when the first signs of paramoebiasis were observed) and October (when mass mortalities of sea urchins occurred). At Mill Cove, temperatures plummeted to $6^{\circ} \mathrm{C}$ in early September but rapidly returned to high values by mid September and remained high throughout October (when mass mortalities of sea urchins occurred).

Monthly SST records for August-November in Halifax Harbour show a strong positive deviation $\left(\sim 3^{\circ} \mathrm{C}\right)$ in August 1993 from the long-term average, average or below average temperatures in 1994, and consistently above average temperatures in 1995 (Fig. 4). Thus, the pattern of interannual variation in sea temperature at Halifax is consistent with that at our 2 study sites. These 3 sites, which occur in different embayments, span a straight-line distance of $75 \mathrm{~km}$ along the Atlantic coast. The positive deviations in 1993 and 1995, when the recent outbreaks of paramoebiasis occurred, were similar in magnitude to those observed in the early 1980 s during previous outbreaks of the disease (Fig. 4).

The coastal warming index, based on satellitederived SST measurements in our study grid during the peak in the annual temperature cycle (August and September), showed peak values over the Scotian Shelf between mid August and mid September 1993 and in the latter half of August 1995 (Fig. 5). These were periods which directly preceded outbreaks of paramoebiasis on the coast. The index was relatively low and similar in the year between outbreaks (1994) and in the 2 preceding years (1991 and 1992). The interannual pattern is consistent with that recorded at our study sites and at Halifax Harbour over this period.

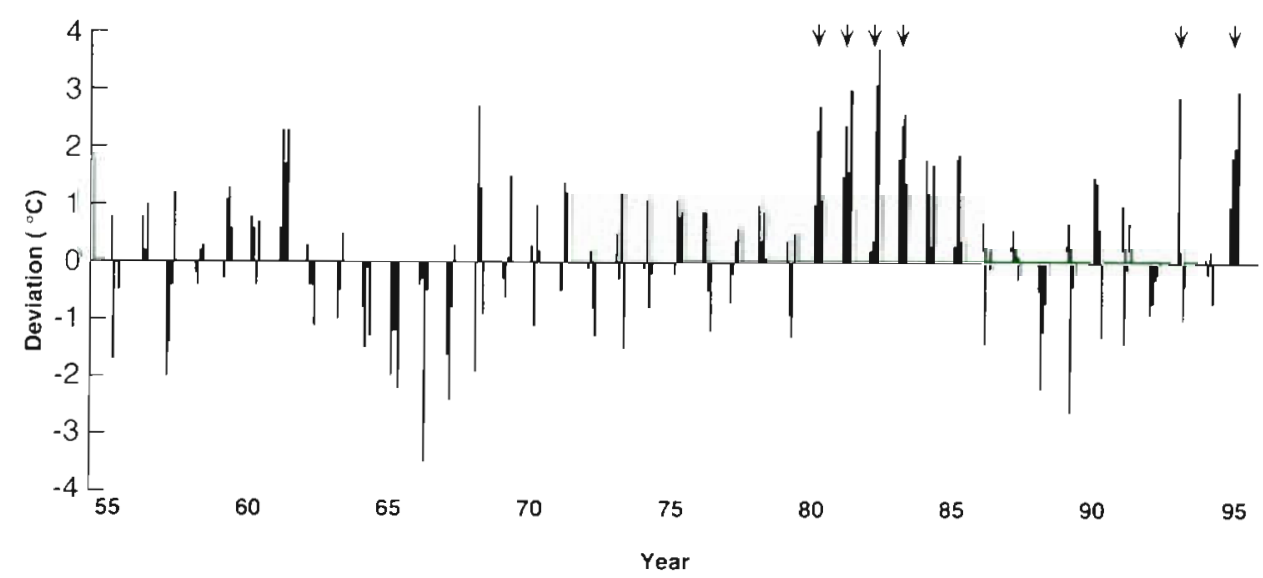

Fig. 4. Deviations in summer/fall (August-November) monthly mean sea surface temperatures (SST) from long-term (1926 to 1967) monthly averages for Halifax Harbour, Nova Scotia. Arrows indicate mass mortality of sea urchins 


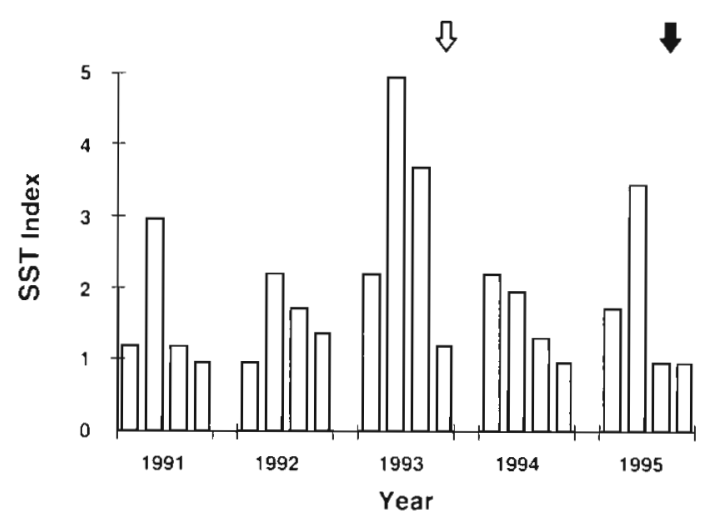

Fig. 5. Coastal warming index based on SST for $2 \mathrm{wk}$ intervals in August and September, 1991 to 1995. See 'Methods' and Table 1 for derivation of this index. Arrows indicate partial (open arrow) and near-complete (solid arrow) mass mortality of sea urchins

\section{Warm-core ring and storm activity off the Scotian Shelf}

The average number of Gulf Stream warm-core rings within or contacting our SST study grid in August and September generally ranged between 1 and 2 (based on counts in 3 to 5 mapping intervals per $2 \mathrm{wk}$ period) and showed no consistent temporal pattern. either among $2 \mathrm{wk}$ intervals within each year or among years (Fig. 6)

The storm index, based on the intensity and duration of hurricanes and tropical storms in the northwest Atlantic, showed the highest levels of storm activity over a 20 yr period in 1981 and 1995, both years of extensive epizootics and widespread mass mortality of Strongylocentrotus droebachiensis in Nova Scotia (Fig. 7). The next 3 highest levels of storm activity were all in years $(1980,1982$, and 1993) in which the disease

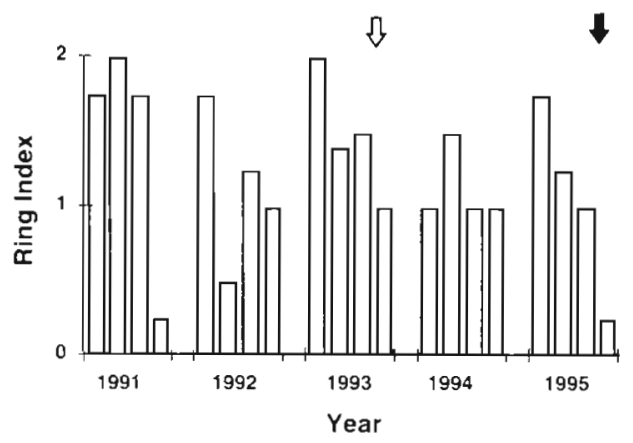

Fig. 6. Warm-core Gulf Stream ring index for 2 wk intervals in August and September, 1991 to 1995. See 'Methods' for derivation of this index. Arrows indicate partial (open arrow) and near-complete (solid arrow) mass mortality of sea urchins

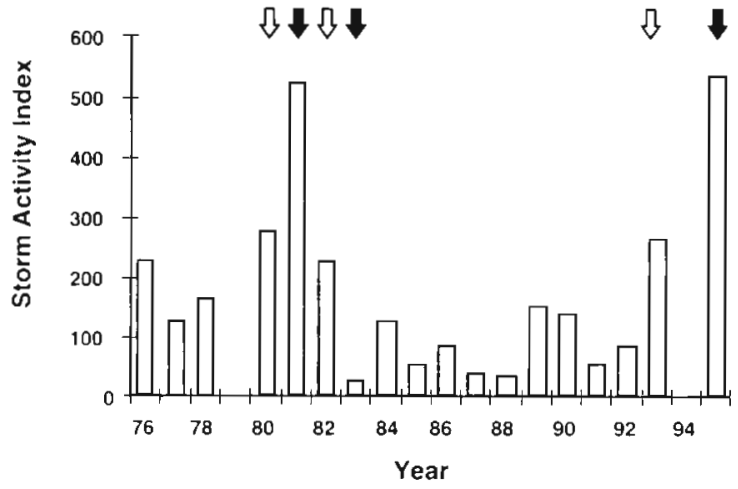

Fig. 7. Storm activity index for August and September, 1976 to 1995. See 'Methods' for derivation of this index. Arrows indicate partial (open arrow) and near-complete (solid arrow) mass mortality of sea urchins

occurred but was localized and/or resulted in incomplete mortality of sea urchins. Only 1983 does not fit this pattern of mortality coincident with high storm activity since there was little storm activity in our grid but extensive mass mortalities of sea urchins.

\section{DISCUSSION}

\section{Role of sea temperature in outbreaks of disease}

Outbreaks of paramoebiasis in Strongylocentrotus droebachiensis in 1993 and 1995, as in the early 1980 s (Scheibling \& Stephenson 1984, Miller 1985, Scheibling 1986), occurred shortly after the peak of the annual cycle of sea temperature $\left(16\right.$ to $\left.18^{\circ} \mathrm{C}\right)$. During both series of epizootics, differences in sea urchin mortality between sites and years were associated with spatial and temporal differences in temperature regimes. Sharp dips in bottom temperature (below $10^{\circ} \mathrm{C}$ ) in late August and late September 1993 at Mill Cove, which probably slowed the progression of the disease, may account for the low incidence of mortality at this site compared to Little Duck Island in that year. Field and laboratory studies have shown that paramoebiasis in $S$. droebachiensis spreads rapidly at peak temperatures $\left(>15^{\circ} \mathrm{C}\right)$ but the disease does not progress, and may not even be transmitted, at temperatures $<10^{\circ} \mathrm{C}$ (Scheibling \& Stephenson 1984, Scheibling 1988). Extreme densities of sea urchins at Little Duck Island in 1993, particularly along the grazing fronts, also may have accelerated the propagation of the disease. The mortality at Little Duck Island was arrested in October/November 1993 as bottom temperatures dropped below the $10^{\circ} \mathrm{C}$ threshold. Winter temperatures at both sites $\left(<0^{\circ} \mathrm{C}\right.$ in February and March 1994) were well below the lower tolerance limit of 
Paramoeba invadens $\left(-5^{\circ} \mathrm{C}\right)$ established in laboratory culture experiments (Jellett \& Scheibling 1988a).

In 1994 there was no evidence of disease at either of our sites, nor were there any reports of disease or unusual mortality of Strongylocentrotus droebachiensis elsewhere along the coast of Nova Scotia during the 1994-95 sea urchin fishing season. At Little Duck Island, summer and fall sea temperatures were relatively low, with peaks at $-14^{\circ} \mathrm{C}$. The disease is transmitted at $14^{\circ} \mathrm{C}$ and progresses to overt signs of morbidity, but only about half as fast as it does at $16^{\circ} \mathrm{C}(16 \mathrm{~d}$ vs $8 \mathrm{~d}$ to morbidity in $50 \%$ of infected sea urchins, Scheibling \& Stephenson 1984). At Mill Cove, peak temperatures varied between 14 and $18^{\circ} \mathrm{C}$ between July and October 1994. If sea urchins at Mill Cove were infected with Paramoeba invadens, they should have exhibited some signs of disease during this 4 mo period. In 1995. both sites experienced an extended period of peak temperalures $\left(>15^{\circ} \mathrm{C}\right)$ between August and October, during which time there was nearly complete mortality of sea urchins.

Between year differences in summer/fall sea temperatures observed at our study sites in the shallow nearshore zone were consistent with the general pattern indicated by our coastal warming index for August and September 1993 to 1995 . These interannual differences may reflect variation in large-scale oceanographic processes influencing the coastal environment of Nova Scotia, such as wind-driven coastal upwelling (Petrie et al. 1987) or cross-shelf advection of water masses (e.g. by storm forcing or entrainment by warm-core rings, see below). The interannual and regional differences in mortality rate and sea temperature that we observed in 1993 and 1995 were similar to those recorded during previous epizootics in the early 1980s (Scheibling \& Stephenson 1984, Miller 1985, Scheibling 1986, 1988), confirming that the severity of an epizootic is determined both by the magnitude and the duration of peak temperatures. Thus, sea urchin mortality is widespread and nearly complete in the shallow subtidal zone when outbreaks of paramoebiasis occur during years of protracted, high $\left(>15^{\circ} \mathrm{C}\right)$ peak summer/fall temperatures. Mortalites are more localized and less severe when epizootics occur in years when peak temperatures are lower and/or of shorter duration. Other conditions affecting the spread of the disease, and therefore the severity of an epizootic, are sea urchin density and long-shore currents which transport the pathogenic agent (Scheibling \& Stephenson 1984, Miller 1985, Scheibling 1988).

\section{Evidence for an exotic pathogen?}

The association of outbreaks of paramoebiasis in Strongylocentrotus droebachiensis with increased coastal warming may reflect large-scale advective processes which not only produce favourable environmental conditions for an epizootic, as mentioned above, but also deliver an exotic pathogen. For example, wind is an important driving force of ocean currents on continental shelves (Mann \& Lazier 1991). Long-shelf winds may induce cross-shelf Ekman transport which can carry planktonic organisms, such as amoebae, towards or away from the coast depending on the wind direction. Myers \& Drinkwater (1988/89) developed a simple Ekman model to examine crossshelf transport of fish eggs and larvae on the Scotian Shelf in relation to recruitment variability in northwest Atlantic fish stocks. Their model indicated that much of the variability in Ekman transport occurred on decadal time scales, although they found no relationship between simulated off-shelf advection of eggs and larvae and subsequent recruitment to fish stocks. Our coastal warming index suggests a relationship between the cross-shelf pattern of SST off Nova Scotia and outbreaks of paramoebiasis in recent years. This association may reflect a wind-driven advective process which influences the supply of both warm water masses and Paramoeba invadens to coastal regions.

Extreme wind forcing associated with passing tropical storms and hurricanes can have dramatic and lasting effects on local circulation patterns and advective transport of planktonic organisms (Drinkwater 1989) For example, Petrie \& Drinkwater (1978) attributed a 2 -fold reduction in lobster larvae in St. Georges Bay, Nova Scotia, to wind-induced advection during the passage of Hurricane Blanch in July 1975. We have shown a strong positive association between outbreaks of disease in Strongylocentrotus droebachiensis and storm activity in the northwest Atlantic during the summer/fall hurricane season. Furthermore, 2 of the most severe epizootics in the last 2 decades occurred in years $(1981,1995)$ of unusually high storm activity (only 1983 is inconsistent with this pattern). Clearly, the impact of passing storms on coastal circulation will depend upon the direction of individual storm tracks and their proximity to the coast, which are not considered in our simple index based on wind intensity and duration. Nevertheless, the index presents further evidence linking epizootics to large-scale meterologic/ oceanographic events which could influence crossshelf transport of an exotic planktonic pathogen.

Another mechanism of cross-shelf advection is intrusion of Gulf Stream meanders and the warm-core rings which spin off from them (Churchill et al. 1986). These rings are meso-scale eddies that can move large volumes of warm Sargasso Sea water (and associated tropical and subtropical species) into the slope water of the northwest Atlantic (Joyce \& Weibe 1983, Craddock 
et al. 1992). These rings are only partially mixed with slope water during their limited life span; most are resorbed by the Gulf Stream within a few months (Craddock et al. 1992). If Paramoeba invadens is an exotic species, it is unlikely that it is carried within the warm-water core of these rings because Jellett \& Scheibling (1988a) demonstrated that the amoeba could not survive in culture at $27^{\circ} \mathrm{C}$. However, the movement of these cyclonic eddies also entrains large volumes of slope and shelf water which presumably results in mixing and advective transport of planktonic organisms, such as fish larvae (Flierl \& Wroeblewski 1985), across the shelf. Myers \& Drinkwater (1989) found evidence that a reduction in recruitment of groundfish stocks in the northwest Atlantic is associated with increased warm-core ring activity which may transport the larvae offshore. Mass transfer of shelf water offshore by entrainment must be balanced by an onshore cross-shelf flow. Myers \& Drinkwater (1989) also showed that the shelf-slope front occurred closer to shore at times of increased ring activity, suggesting that the rings push the front shoreward. We found consistent numbers of rings in our study area between 1991 and 1995 and therefore no direct relationship between ring frequency and sea urchin epizootics. However, this does not necessarily discount the possibility that Gulf Stream intrusions contribute to the transport of an exotic pathogen. Myers \& Drinkwater (1989) also found that the number of rings in their sampling regions varied little (usually 1 or 2 rings per sampling interval) among years from 1973 to 1986. As these authors point out, many factors interact to determine the distribution and abundance of planktonic organisms. Advection and mixing associated with Gulf Stream intrusions, for example, may be accelerated by large storm events such as hurricanes (Craddock et al. 1992).

The occurrence of various subtropical and tropical fish species in coastal waters off Nova Scotia in late summer and fall (A. Hebda, Nova Scotia Museum, Halifax, pers. comm.) is further evidence of cross-shelf advection which could transport a planktonic pathogen. In 1995, there were reports of tropical fish and sea turtles in the shallow nearshore waters immediately preceding the sea urchin epizootic. Observations of exotic species contribute to the body of circumstantial evidence suggesting mechanistic links between outbreaks of sea urchin disease and meteorologic and oceanographic features. Moreover, the endemic pathogen hypothesis is inconsistent with the absence of disease in 1994, when temperatures reached similar peaks as in the adjoining years and sea urchins were abundant. This hypothesis also is inconsistent with laboratory findings that the Paramoeba invadens cannot be maintained in culture at $2^{\circ} \mathrm{C}$ (Jellett \& Scheibling
1988 ), which is above the winter sea temperature (0 to $-2^{\circ} \mathrm{C}$ ) in the nearshore waters of Nova Scotia.

Clearly, further research is required to resolve the issue of the source of the pathogenic amoebae. Although we were unable to detect Paramoeba invadens either in the water column or in sea urchins during periods between epizootics (Jellett et al. 1989), it is possible that our sampling procedures were inadequate or that the amoebae may reside in some alternative host or habitat that we have not sampled (Miller 1990, but see also Jellett et al. 1990). Tracking $P$. invadens in the water column and/or sediments throughout the course of an epizootic (when the amoebae presumably are most abundant) and over winter is a more promising approach. A decline in the abundance of the amoebae with decreasing water temperature is expected, and their gradual disappearance at low winter temperatures would support the conclusion that they are not endemic. However, even if it can be shown that $P$. invadens is a non-resident, the questions of where the infective amoebae originate and how they are transported to the coast of Nova Scotia are still to be answered.

\section{Implications for ecosystem dynamics and the sea urchin fishery}

Disease is a key factor controlling the dynamics of the racky subtidal system off Nova Scotia (Scheibling $1984,1986,1988$, Miller 1985). In the absence of disease, sea urchin populations in the shallow subtidal zone eventually expand through migration and recruitment and destructively graze the kelp (Scheibling et al. 1994, unpubl. data). These populations can persist indefinitely on barren grounds, although rates of growth and reproduction decline as the sea urchins adjust to poorer nutritional conditions (Lang \& Mann 1976, Johnson \& Mann 1982). Thus, if outbreaks of paramoebiasis are mediated by stochastic oceanographic and meterological events, the ecosystem can remain in the barren ground state for variable and indeterminant periods. The barren ground state persisted for about a decade following destructive grazing in St. Margaret's Bay in the early 1970s (Mann 1977. Chapman 1981), and probably much longer along other parts of the Atlantic coast of Nova Scotia (Wharton \& Mann 1981), before sea urchins were eliminated by disease (Miller \& Colodey 1983, Miller 1985. Scheibling 1986). However, the destructive grazing of kelp beds along much of this coast in the early $1990 \mathrm{~s}$ was terminated before the conversion was complete by a major epizootic in 1995. The transition to kelp beds after an extensive sea urchin die-off follows a relatively deterministic successional process which culmi- 
nates in luxuriant kelp beds within 2 to 3 yr (Miller 1985, Scheibling 1986, Johnson \& Mann 1988). Thus, we expect to see kelp beds re-established in diseaseaffected areas of the coast by 1998 .

Finally, the widespread outbreak of paramoebiasis in 1995 has had a serious impact on the recently expanding sea urchin fishery in Nova Scotia. Given the history of recurrent outbreaks of this disease, and the apparent unpredictability of these events, the sea urchin fishery is destined to periodically crash. Further research into the source of the pathogenic agent may suggest ways in which the fishery might be managed to minimize or ameliorate the effects of this devastating disease (e.g. harvesting in advance of a predicted outbreak or transferring stocks to deeper and cooler water). Until such time, the fishery off this coast will likely remain a 'boom and bust' venture.

Acknowledgements. We thank Toby Balch, Susanne Meidel, and Ian Dempsey for assistance with field work and Eric Scheibling for help in analyzing oceanographic and meterologic data. We are very grateful to Lt. Com. Corradini at METOC and Ed Verge at Bedford Instutute of Oceanography for providing unpublished sea temperature data, and to Joanne Jellett of Jellett Biotek Ltd. for culturing sea urchin tissues and identifying the pathogenic amoeba. We also thank Ken Drinkwater and Brian Petrie at Bedford Institute of Oceanography for helpful discussions on coastal oceanography, and the following urchin fishers for supplying valuable information on the spread of the sea urchin disease in 1995: Jamie Atwood, Ian Barkhouse, William Bond, Paul Boudreski, William Burke, Mike Craig, Raymond Garland, Mike Kelly, Phillip MacDonald, Andy Schnare, Chris Theriault, Lee Thorburn, and Sean Wilkie. The research was funded by a Research Grant to R.E.S. from the Natural Sciences and Engineering Research Council of Canada.

\section{LITERATURE CITED}

Boudouresque CF, Nedelec H, Shepard SA (1980) The decline of a population of the sea urchin Paracentrotus lividus in the Bay of Port-Cros (Var, France). Trav Sci Parc Nation Port-Cros Fr 6:243-251

Chapman ARO (1981) Stability of sea urchın dominated barren grounds following destructive grazing of kelp in St. Margaret's Bdy, eastern Canada. Mar Biol. 62:307-311

Christie H, Lemaas HP, Skadsheim A (1995) Local patterns in mortality of the green sea urchin, Strongylocentrotus droebachiensis, at the Norwegian coast. In: Skjoldal HR, Hopkins C, Erikstad KE, Leinaas HP (eds) Ecology of fjords and coastal waters. Elsevier, Amsterdam, p 573-584

Churchill JH, Cornillon PC, Milkowski GW (1986) A cyclonic eddy and shelf-slope water exchange associated with a Gulf Stream warm-core ring. J Geophys Res 91: 9615-9623

Craddock JE. Backus RH, Daher MA (1992) Vertical distribution and species composition of midwater fishes in the warm-core Gulf Stream meander/ring $82-H$. Deep Sea Res 39:5203-5218

Drinkwater K (1989) The response of an open embayment to near-hurricane force winds. Cont Shelf Res 9:823-839
Flierl GR, Wroeblewski JS (1985) The possible influence of warm core Gulf Stream rings upon shelf water larval fish distribution. Fish Bull 83:313-330

Gregory D, Verge E, Langille P (1993) Long-term temperature monitoring program 1991/1992 Scotia Fundy and the Gulf of the St. Lawrence. Can Data Rep Hydrogr Ocean Scl, No. 120

Gregory D, Verge E, Langille P, Creaser S (1994) Long-term temperature monitoring program 1993 Scotia Fundy and the Gulf of the St. Lawrence. (an Data Rep Hydrogr Ocean Sci, No. 127

Hagen NT (1987) Sea urchin outbreaks and nematode epizootics in Vestfjorden, Northern Norway. Sarsia 68: $177-229$

Hagen NT (1992) Macroparasitic epizootic disease: a potential mechanism for the termination of sea urchin outbreaks in Northern Norway? Mar Biol 114:469-478

Hagen NT (1996) Parasitic castration of the green echinoid Strongylocentrotus droebachiensis by the nematode endoparasite Echinomermella matsi: reduced reproductive potential and reproductive death. Dis Aquat Org 24: $215-226$

Jellett JF, Novitsky J, Cantley J, Scheibling RE (1.989) Nonoccurrence of Paramoeba invadens in the water column and sediments off Halifax, Nova Scotia. Mar Ecol Prog Ser 56:205-209

Jellett JF, Novitsky J, Cantley J, Scheibling RE (1990) Rebuttal to R. J. Miller's comment on Jellett et al. (1989). Mar Ecol Prog Ser 63:307-308

Jellett JF, Scheibling RE (1988a) Effect of temperature and food concentration on the growth of Paramoeba invadens (Amoebida: Paramoebidae) in monoxenic culture. Appl Environ Microbiol 54:1848-1854

Jellett JF, Scheibling RE (1988b) Virulence of Paramoeba invadens Jones (Amoebida, Paramoebidael from monoxenic and polyxenic culture. J Protozool 35:420-422

Johnson CR, Mann KH (1982) Adaptations of Strongylocentrotus droebachiensis for survival on barren grounds in Nova Scotia. In: Lawrence JM (ed) Echinoderms: Proceedings Int Echinoderms Conf, Tampa Bay. AA Balkema, Rotterdam, p 277-285

Johnson CR, Mann KH (1988) Diversity, patterns of adaptation, and stability of Nova Scotian kelp beds. Ecol Monogr 58:129-154

Johnson PT (1971) Studies of diseased sea urchins from Point Loma. Kelp Habitat Improvement Project, Annual Report, 1970-1971 California Institute of Technology, Pasadena, p $82-90$

Jones GM (1985) Paramoeba invadens n. sp. (Amoebida: Paramoebidae), a pathogenic amoeba from the sea urchin Strongylocentrotus droebachiensis in Eastern Canada. J Protozool 32:564-569

Jones GM, Hagen NT (1987) Echnomermella matsi n. sp. an endoparasitic nematode from the sea urchin Strongylocentrotus droebachiensis in northern Norway. Sarsia 72 : $203-212$

Jones GM, Hebda AJ, Scheibling RE, Miller RJ (1985a) Histopathology of the disease causing mass mortality of sea urchins (Strongylocentotus droebachiensis) in Nova Scotia. J Invertebr Pathol. 45:260-271

Jones GM, Scheibling RE (1985) Paramoeba sp. (Amoebida, Paramoebidae) as the possible causative agent of sea urchin mass mortality off Nova Scotia. J Parasitol 71 : $559-565$

Jones GM, Scheibling RE, Hebda AJ, Miller RJ (1985b) Paramoeba sp. (Amoebida: Paramoebidae) in tissues of diseased sea urchins (Strongylocentrotus droebachiensis) 
in Nova Scotia. In: Keegan BF, O'Conner BDS (eds) Echinodermata: Proc 5th Int Echinoderms Conf, Galway. AA Balkema, Rotterdam, p 289-294

Joyce TM. Weibe PH (1983) Warm-core rings of the Gulf Stream. Oceanus 26:34-44

Lang C, Mann KH (1976) Changes in sea urchin populations after the destruction of kelp beds. Mar Biol 36:321-326

Lauzier LM, Hull JH (1969) Coastal station data:temperatures along the coast 1921-1969. Fish Res Bd Can Tech Rep No 150

Lessios HA (1988) Mass mortality of Diadema antillarum in the Caribbean: what have we learned? Annu Rev Ecol Syst 19:371-393

Lessios HA, Robertson DR, Cubit CD (1984) Spread of Diadema mass mortality in the Caribbean. Science 226:335-337

Maes P. Jangoux M (1984) The bald sea urchin disease: a biopathological approach. Helgol Wiss Meeresunters 37 : $217-224$

Maes P, Jangoux M (1985) The bald-sea-sea urchin disease: a bacterial infection. In: Keegan BF, O'Conner BDS (eds) Echinodermata: Proc 5th Int Echinoderms Conf, Galway. AA Balkema, Rotterdam, p 313-314

Mann KH (1977) Destruction of kelp-beds by sea-urchins: a cyclical phenomenon or irreversible degradation? Helgol Wiss Meeresunters 30:455-467

Mann KH, Lazier JRN (1991) Dynamics of marine ecosystems. Blackwell, Boston

Miller RJ (1985) Succession in sea urchin and seaweed abundance in Nova Scotia, Canada. Mar Biol 84:275-286

Miller RJ (1990) Comment on Jellett et al. (1989). Mar Ecol Prog Ser 63:305-306

Miller RJ, Colodey AG (1983) Widespread mass mortalities of the green sea urchin in Nova Scotia. Mar Biol 73:263-267

Myers RM, Drinkwater KF (1988/89) Onshelf Ekman transport and larval fish survival in the Northwest Atlantic. Biol Oceanogr 6:45-64

Myers RM. Drinkwater KF (1989) The influence of Gulf Stream warm core rings on recruitment of fish in the northwest Atlantic. J Mar Res 47:635-656

Pearse JS, Costa DP, Yellin MB, Agegian CR (1977) Localized mass mortality of red sea urchins (Strongylocentrotus franciscanus, near Santa Cruz, California. Fish Bull US 75: 645-648

Petrie B, Drinkwater KF (1978) Circulation in an open bay J Fish Res Bd Can 35:1631-1635

Petrie B, Topliss BJ, Wright DW (1987) Coastal upwelling and eddy development of Nova Scotia. J Geophys Res 29: $12979-12991$

Scheibling RE (1984) Echinoids, epizootics and ecological stability in the rocky subtidal off Nova Scotia, Canada Helgol Wiss Meeresunters 37:233-242

This article was submitted to the editor
Scheibling RE (1986) Increased macroalgal abundance following mass mortalities of sea urchins (Strongylocentrotus droebachiensis) along the Atlantic coast of Nova Scotia. Oecologia 68:186-198

Scheibling RE (1988) Biological control of sea urchins: Achilles' heel or Pandora's box? In: Burke R, Mladenov PV, Lambert P, Parsley PL (eds) Echinoderms biology: Proc 6th Int Echinoderms Conf, Victoria. AA Balkema, Rotterdam, p $745-754$

Scheibling RE (1994) Interactions among lobsters, sea urchins and kelp in Nova Scotia, Canada. In: David B, Guille A, Feral JP, Roux M (eds) Echinoderms through time: Proc 8th Int Echinoderms Conf, Dijon. AA Balkema, Rotterdam, p 865-870

Scheibling RE (1996) The role of predation in regulating sea urchin populations in eastern Canada. Oceanol Acta 19: $421-430$

Scheibling RE, Hatcher BG (1993) Prospects for the sea urchin fishery off Nova Scotia: boom or bust. The year of the underutilized species, a workshop sponsored by Department of Fishersies and Oceans, Canada. Moncton, New Brunswick

Scheibling RE, Hennigar A, Balch T (1994) The dynamics of destructive grazing of kelp beds by sea urchins in Nova Scotia. In: David B, Guille A, Feral JP, Roux M (eds) Echinoderms through time: Proc 8th Int Echinoderms Conf. Dijon. AA Balkema, Rotterdam, p 871

Scheibling RE, Stephenson RL (1984) Mass mortality of Strongylocentrotus droebachiensis (Echinodermata: Echinoidea) off Nova Scotia, Canada. Mar Biol 78: $153-164$

Sivertsen K (1996) Incidence, occurrence and distribution of the nematode Echinomermella matsi in its host, Strongylocentrotus droebachiensis, in northern Norway. Mar Biol 126:703-714

Skadsheim A, Christie H, Leinaas HP (1995) Population reductions of Strongylocentrotus droebachiensis (Echinodermata) in Norway and the distribution of its endoparasite Echinomermella matsi (Nematoda). Mar Ecol Prog Ser 119:199-209

Stien A. Halvorsen O, Leinaas HP (1995) No evidence of Echinomermella matsi (Nematoda) as a mortality factor in a local mass mortality of Strongylocentrotus droebachiensis (Echinoidea) In: Skjoldal HR, Hopkins C, Erikstad KE, Leinaas HP (eds) Ecology of fjords and coastal waters. Elsevier, Amsterdam, p 585-597

Wharton WG, Mann KH (1981) Relationship between destructive grazing by the sea urchin, Strongylocentrotus droebachiensis, and the abundance of American lobster, Homarus americanus, on the Atlantic coast of Nova Scotia. Can J Fish Aquat Sci 38:1339-1349

Manuscript first recelved: December 10, 1996

Revised version accepted: March 19, 1997 